\title{
Prosecuting Domestic Abuse in England and Wales: Crown Prosecution Service 'working practice' and New Public Managerialism
}

\begin{abstract}
The Crown Prosecution Service (CPS) regards offences of domestic abuse as 'particularly serious' (CPS, 2014) and considers tackling violence against women a 'priority' (CPS, 2017a). This article examines how criminal prosecutors in England and Wales approach cases of intimate partner abuse in practice, specifically at the point when a complainant no longer wishes to support the prosecution. It first introduces 'New Public Managerialism' (NPM). This is the lens through which the qualitative responses of a sample of 9 prosecutors are thematically analysed. Second, the primary research indicates a prosecutorial tendency or 'working practice' in 2017 disinclined to terminate cases on request, prompting instead the routine or habitual use of 'witness summons'. Third, the article exposes how techniques of NPM have contributed to the identified 'working practice' often in concealed and unintended ways. Managerial priorities in this context appear to have restricted the free exercise of the prosecutor's discretion to take decisions on a case by case basis. The implications for women's safety and autonomy are considered.
\end{abstract}

\section{Key Words}

Domestic Violence and Abuse, Crown Prosecution Service, Managerialism

\section{Introduction}

The Crown Prosecution Service (CPS) is charged with the responsibility of implementing the 'prosecutive power of the state' in England and Wales (Bennion, 1986: 3). Its inception in 1986 came on the back of centuries of 'notoriously ramshackle' police prosecutions that had been piecemeal in approach and undirected and non-uniform across geographies (Bennion, 1986: 3). In a bid to bring consistency, the CPS now routinely publishes policy objectives to guide individual prosecutorial discretionary decision making. In the area of intimate partner abuse, echoing the demands of women's groups, changing social attitudes and the UK government's wider strategy to end Violence Against Women and Girls (HM Government, 2016), CPS policy confirms it is endeavouring 'to bring more perpetrators to justice' (CPS, 2017a).

The first CPS domestic violence policy statement came in 1993. It pledged to prosecute all evidentially viable cases in the public interest in a bid to address wider concerns that the criminal justice system (CJS) was failing to do enough to protect abused women in the private sphere (House of Commons Report from the Select Committee on Violence in Marriage, 1975; Gottschalk, 2006). It also followed specific criticism of the CPS that too few 
cases were being charged, too many cases were having charge levels reduced and that discontinuance rates were too high (Burton, 2008; 93; Cretney and Davis, 1997; 147- 8). The CPS was only therefore delivering 'modest achievement' in such cases (Cretney and Davis, 1997; 147). Despite police services simultaneously introducing pro-arrest policies in 1993 (Hoyle and Sanders, 2000; 17) the CPS policy statement resulted in insignificant shifts in working practices. Consequently, in 2005 there came a CPS policy restatement and, alongside it, mandatory domestic violence training for all prosecutors (CPS, 2008). Training was delivered nationally between 2005 to 2008 and definitively signalled the crime's augmented priority within the organisation (Hall, 2012; 143-149).

Current Domestic Abuse Guidelines for Prosecutors continue to regard the offence as 'particularly serious' (CPS, 2014) and a 'priority' (CPS, 2017a). As such, the CPS celebrates its year on year increases to the domestic abuse conviction rate which last year saw, once again, its highest ever recorded rate: $75.7 \%$ (CPS, 2017a). Such open and unqualified celebration of the improved rate of convicted offenders inevitably sets the tone that 'success' in these cases for the CPS equates to convictions.

Nonetheless victim withdrawal from the criminal justice process remains a significant obstacle to successful domestic abuse convictions (ONS, 2016; CPS, 2016). ${ }^{1}$ Prosecutors must therefore regularly confront the question of how to proceed when the victim expresses her wish for discontinuance. Succinctly put, prosecutors can either accede to her request ${ }^{2}$ or decide to pursue the prosecution, absent her support. 'Victimless' prosecutions can be achieved where a 'realistic prospect of conviction'4 exists without requiring the victim to give evidence at trial, provided other corroborative evidence allows. Such evidence might include police body worn video footage, 999 emergency calls, medical records of injuries or third-party witness testimony (see Bettinson and Bishop, 2017). ${ }^{5}$ However, alternative evidential opportunities are not always available hence prosecutors may request the court issue a summons to secure the victim's attendance at trial. ${ }^{6}$

Using data from nine semi-structured interviews with prosecutors based in the South of England, the article examines whether an identifiable 'working practice' or typical way of proceeding, when the complainant withdraws, can be identified (see methodology below). It explores how stated CPS claims to 'prioritise' (CPS, 2017a) Violence Against Women are performed by this sample in practice. Despite CPS guidance to prosecutors asserting that to compel or 'summons' an unsupportive victim to give evidence at trial should be the prosecutor's 'last resort' (CPS, 2014), the primary research reveals that prosecutors in the sample in fact routinely rely on summons (albeit there are preliminary indications that prosecutors are beginning to step back from this presumption to summons). Having identified a tendency or 'working practice' of prosecutorial reliance on summons, the article uncovers how techniques of New Public Managerialism have contributed, often in clandestine ways, to restrict the true free exercise of prosecutorial discretion to consider DA on a case by case basis.

The article therefore contributes to and updates existing knowledge about prosecutorial 'working practice' in domestic abuse (DA) cases. Moreover, it makes the original observation about how techniques of New Public Managerialism can operate to restrict professional 
discretion in the CPS, encouraging here the use of witness summons. Such a habitual working practice has implications for women's safety and impacts the potential of criminal justice intervention to contribute to empowering outcomes for her. Before outlining the 'working practice' and its emergence in the context of managerial demands, the article outlines its methodology and its lens, New Public Managerialism.

\section{Methodology}

This research was made possible as a result of a scholarship fund granted by Kent Law School. Having obtained ethical approval from the School, I wrote individually to prosecutors inviting them to take part, anonymously, in the research. As the project became known locally, prosecutors I had not approached directly volunteered themselves and gave me contact details of other potential interviewees. The sample was thus built from my initial local knowledge of prosecutors, networking and the effect of 'snowballing'. The sample was drawn from one CPS area in the South of England; a region comprising rural areas and urban and coastal conurbations.

Despite the diversity of the region and the CPS organisational structure being representative of the institution as a whole, caution must be exercised in suggesting the potential for national generalisability of the primary research; mindful in particular of the sample's small scale. It is possible that the 'working practice' identified in the sample might have evolved within local offices and subsequently re-enforced between proximate colleagues. Given the limitations of the sample due to its size and geographic confines, the value of the work is not to assert a conclusive state of affairs or definitive 'working practice'. Rather, as the sample reveals an area tendency for prosecutors in 2017 to rely on summons, its value is to stimulate and animate CPS institutional reflection on one hand and to contribute to literature that explores managerial influences on professional decision-making on the other.

Interviews were guided by the use of a semi-structured interview schedule. The schedule acted as a 'topic guide' (Bell, 2005), prompting me to cover the target areas of enquiry but allowing me flexibility in terms of sequencing the questions. The approach also allowed me some latitude to explore each topic in depth (Yin, 2003) particularly where responses were felt to be significant (Bryman, 2012). The questions were largely open questions which invited extended, or rich (Weick, 2007) responses from the participant prosecutor, thus permitting answers in the prosecutor's own terms not being directed or influenced by me. Interviews were audio recorded and transcripts were prepared for analysis. Transcripts were sent by email for participant comment and/ or amendment. On two occasions I sought clarification with respondents by email.

During the thematic analysis, I familiarised myself with the data before coding and identifying themes (Braun and Clark, 2006). Using Nvivo software, I was able to review each theme allowing me to refine both the specific theme and consider broader overarching patterns based on frequency and significance for the participants. In this way, it became clear that managerialism was a factor that was often playing an unacknowledged part in many of the themes identified as influencing prosecutorial decision-making. As an active researcher I acknowledge my own theoretical and lived position in relation to the data 
(Braun and Clark, 2006) particularly as a former employee and current freelance agent of the CPS. Being aware of my own 'political and intellectual autobiograph[y]' (Mauthner and Doucet, 1998) means that I acknowledge my role in formulating the interview process and the end product. Despite this, throughout the data gathering process and interpretative analysis I endeavoured to apply objective 'art, rigor and creativity' to uncover the 'qualities, meanings and implications of the themes' (Watts, 2014). Before explaining how NPM shapes CPS 'working practice', the next section outlines its strategies and methods.

\section{New Public Managerialism}

The neoliberal state's regulation of all domains by the market and the dissemination of economic principles everywhere is well identified (Larner, 2000; Harvey, 2005; Brown, 2015). Economic ideologies permeate state institutions even where monetary profit is not considered the end goal. Through the rise of neoliberal governance, political and business idiolects converge and shape everyday conduct. If neoliberalism is an 'art of governance' (Foucault, 2004; 131) then, in the public sector, the tenets of New Public Managerialism (NPM) are its masterpiece and the CPS is, I suggest, its quintessence.

In dogmatic neoliberal doctrine market competition is considered a virtue and, at its most doctrinaire, neoliberalism would advance the 'privatisation of all state functions' (Bell, 2011: 140). But the CPS has not been privatised and in the absence of other organisations competing for its core business, the CPS is effectively encouraged to compete with itself for improved conviction rates, victim satisfaction, efficiency and meeting reduced budgetary targets year on year. In this way, the principles of competition can be seen to operate within the four walls of the CPS. New Public Managerialism is visible in public sector institutions such as health and social services, education, local government (Exworthy and Halford 1999; Stoker; 1999) and was introduced into the criminal justice system by the New Labour government (1997- 2010) to reduce inefficiency (McGlaughlin et al, 2001). NPM expects value for money and productivity and it demands this through system modernisation and the delivery of core quality standards. ${ }^{7}$ Managerialism tends to conceal its profit motives (or in the case of the CPS its money saving interests) with synonyms such as 'performance goals' or 'organisational objectives' (Kilkauer, 2015: 1106) and strives for legitimacy through its quest for productivity, performing self-regulation through regular monitoring of targets.

From the outset, the recommendation to establish the CPS was triggered by 'the need for the efficient and economical use of resources' (Philips, 1981). Thus, the Prosecution of Offences Act 1985 set the expectation that the CPS would make financial savings.

Conservative politicians at the time were also simultaneously wedded to the idea that sheer numbers of police officers, prosecutions and punitive sentencing would have long term deterrent effect (McGlaughlin et al, 2001: 302). Flowing from this premise, coupled with a drive for economy and efficiency, it is easy to draw parallels between the way managerialism has operated in the Crown Prosecution Service since that time and Packer's Crime Control Model (Packer, 1964: 9). The Crime Control Model, according to Packer, aims to repress crime through efficiency in achieving large numbers of convictions; speed and 
finality are prized. By operating a conveyor belt system of justice where cases are dealt with in an efficient, routinised and even stereotyped way, the obstacles to conviction, Packer observes, are diminished. The Crime Control Model proceeds with high volume and, notably, '[t]he model that will operate successfully on these presuppositions must be an administrative almost managerial model' (Packer, 1964: 11).

Managerialism is not then simply a 'modern management method' but an ideology that uses the generic tools of management to 'establish itself systematically in organisations' (Kilkauer, 2015: 1106). As an 'all-pervasive' creature, managerialism has infiltrated 'every aspect of criminal justice' (Garland, 2001; 18) and re-structuring on these principles is widely evident in England and Wales. For example, the prison estate has been privatised, court delay and inefficiency are routinely monitored (Leveson, 2015), forensic science work is 'contracted out' to the private sector following closure of the unprofitable government owned Forensic Science Service in 2010 and, the Offender Management Act 2007 sees corporate trusts compete to run probation services. Moreover, just as the police, the CPS is required to state policy objectives and measure key performance targets. Such changes have led to accusations that substantive justice goals appear usurped by the pursuit of administratively rational ends (Jones, 1993).

It has also been suggested that the effect of 'performance indicators and management measures [has been the narrowing of] professional discretion [within] tightly regulated working practice' (Garland, 2001: 18). Restricting or even depriving employees of decisionmaking powers results in a de-skilling or downgrading of the professional or skilled worker's role (Kilkauer, 2015: 1106). This de-skilling may in part have something to do with the expansion of management personnel who are tasked with overseeing operations. ${ }^{8}$ But it may also be to do with introduction of systems and standardised ways of working aimed at facilitating efficiency. This, paradoxically, also sees non-managerial staff entrusted with delegated responsibilities premised on individual 'initiative' being performed within clearly stated organisational aims or parameters. This apparent contradiction between the expansion of management personnel and yet the re-placement of hierarchical decision making (Jones, 1993; 189) exposes how managerialism, just as its umbrella ideology neoliberalism, may not enjoy rigid intransigent theory. Rather, it might be considered instrumentalist, pragmatically embracing 'what works' (Peck, 2010; 106) to streamline processes and save money. The resulting reduction or narrowing of professional decisionmaking discretion is explored through the empirical research presented here.

As the CPS is tasked with prosecuting 'on behalf of the public and not just in the interests of any particular individual' (CPS, 2017b), state and prosecutor interests are considered synonymous with the victim's. This is because ultimately, the state's correctional policies should serve both public and offender (Matravers, 2010). In the past, the approach attracted criticism as it was perceived that, once the wheels of justice had started rolling, the criminal justice system often marginalised victims, relegating and subsuming her interests by the greater good (Garland, 2001; 121). However, now considered consumers in the market place of criminal prosecutions, victims ought to be 'at the heart' of the criminal justice system (Queen's Speech, 2010); their interests fore fronted. However, as the primary 
research indicates, managerialism's common-sense language (who could be against efficiency and improved conviction rates?) can depoliticise relevant issues (Lacey, 1991) and de-centre the status of the victim. In the case of intimate partner abuse, I argue that managerialism obscures CPS substantive commitments to consider female victims of violence on a case by case basis, laying bare managerialism's shortcomings and contradictions. Thus the 'working practice' described below (the routine use of summonsing reluctant victims of intimate partner abuse) is, I argue, consistent with and fortified by the dominant cultural effects of the managerialist paradigm; effectiveness, efficiency and economy.

\section{Locating the 'working practice' within three available approaches to prosecuting domestic abuse}

Broadly speaking, prosecuting authorities might take three approaches to domestic abuse cases where the victim is no longer supportive. Firstly, there is discontinuance as requested by the victim, or what has been called 'automatic-drop' (Nichols, 2014; 2120). This appears to have been the CPS approach prior to 2008 (Cretney and Davis, 1996) when complainant retraction in the context of prosecuting domestic abuse appeared to have 'an almost singular effect; namely, discontinuance' (Ellison, 2002: 834).

Secondly, there is pursuance of the prosecution irrespective of the woman's request or whether her personal interests are best met by that course. Nichols has called this 'no-drop' approach to prosecution a 'social change' approach because of its potential to challenge the social structures that permit violence against women (Nichols, 2014). This was the approach operating in CPS practice in 2009 immediately following revised guidelines, policy and mandatory training aimed at addressing the preceding praxis of 'automatic drop' (Hall, 2012; 143-149).

Or thirdly, prosecutors may weigh up factors to determine whether the woman's safety and/ or sense of autonomy might be best met through either course. Current CPS guidelines for prosecutors indicate that whilst there is a presumption to prosecute, prosecutors must weigh up the practical, personal and safety reasons outlined in her retraction statement and contained within the police 'risk assessment' before deciding how to proceed. Retraction statements must contain her reasons for withdrawing from the prosecution. Statement takers must specifically include information about whether the perpetrator has intimidated her into withdrawing. Prosecutors are therefore reliant on the police to obtain fair and accurate accounts. However, as her intention in making the statement is to stop proceedings, the expectation that she would then disclose a further offence of witness intimidation is clearly compromised. This third approach has variously been called a 'victiminformed' (Catteneo et al, 2009), 'survivor-defined' (Goodman et al, 2016) or 'victim empowerment' (Hoyle and Sanders, 2000) approach. The CPS has never named the approach but existing domestic abuse policy most closely advocates prosecutors emulate this 'survivor-defined' way.

The first approach, routinely acceding to her wishes and dropping the case accordingly, can be advantageous to the extent that it demonstrates that the criminal justice system is 
responsive to the wants of the victim. Winick has argued that 'being heard' in this way is 'vital to an individual's sense of her own locus of control [and] emotional well-being' (Winick, 2000: 64). She may withdraw from the prosecution because arrest alone achieved cessation of the immediate behaviour as intended or she may have weighed up that the costs of prosecution (breakdown of the family structure, loss of financial support, increased risk of violent retaliation) outweigh the potential benefit of prosecution outcomes. Having her wishes actioned is likely to instil a sense that the CJS is not impersonal, impervious or even coercive, rather it is sensitive and respectful to the victim. Moreover, being victim reactive might forge a sense of trust in the victim to call on the criminal justice system in the future in the knowledge that victim preference is recognised (Buzawa et al, 2000; 17).

Unquestioningly acceding to the victim's request however, is not without notable shortcomings. Advocates of no-drop prosecutions (Wills, 1997; Stark, 1993; Sacuzzo, 1998), often cite the transfer of power to the abuser if victim withdrawal is habitually assented. He may pursue violence, intimidating tactics or 'apologetic manipulations' in an effort to coerce the victim into retracting, knowing that her retraction will have the effect of terminating his prosecution (Nichols, 2015; 2117). No-drop prosecution averts the potential for this power transfer to the perpetrator, ensuring that the burden of whether or not to prosecute is taken out of the victim's hands. Additionally, no-drop prosecutions which remove, or largely remove, the prosecutor's exercise of discretion to discontinue the case recognise that often victims cannot be relied upon to bring offenders to account - either because they retract, minimise, or fail to attend court. Wills reminds us that this is because 'many battered women fail to see that criminal intervention can assist in the shared goal of getting their abuser to stop the violence' (Wills, 1997; 178). Requiring criminal intervention therefore ensures any benefit that the victim might receive from CJS is facilitated.

However, if it is the State's responsibility or aim to keep women safe, no-drop prosecutions appear to contradict the effort. Many women who have experienced no-drop practices subsequently lose confidence in criminal justice agents' ability to act in their best interests, even in moments of future emergency (Buzawa et al, 2000). ${ }^{9}$ Acknowledging potential benefits of both approaches, the third strategy recognises that inflexibly pursuing the prosecution has disadvantages in two basic forms; it might either increase the victim's risk of harm whilst being involved in proceedings or immediately after (absent protections such as safe housing or defendant remand into custody) or it might instil victim reluctance to call police in an emergency in the future (Catteneo et al, 2009: 1229). Particularly in the United States the practice has been shown to work against non-white and poor women bearing in mind the immigration and child custody consequences of involving the State (Maguigan, 2003: 433).

Furthermore, the 'survivor defined' approach recognises that no-drop prosecutions can have the effect of overlooking women's agency. Whilst acknowledging that the woman's decision may not be entirely free because it is formed in coerced circumstances, the third approach understands the decision might still be entirely considered. For that reason, a woman's wishes ought not to be immediately discounted as arising from perpetrator manipulations on the one hand or 'learned helplessness' (Walker, 2016; Jones, 1999) on the other. The decision may be formed by someone with astute awareness, acting wisely in the 
circumstances bearing in mind personal, practical or safety factors, particularly if she intends to maintain the relationship. The victim's request and reasons should therefore, ordinarily, form part of the prosecutor's determination, bearing in mind the autonomy enhancing potential of effecting the victim's wishes. This case by case, 'third way' is the approach that the CPS ostensibly adopts in its policy (CPS, 2017a) and guidelines (CPS, 2014). The following section uses the primary research to consider the extent to which it is actually practiced.

\section{Prosecutorial 'working practice' in 2017}

Of the sample of nine prosecutors interviewed, ${ }^{10}$ three prosecutors with sufficiently long tenure were indeed able to identify that prior to 2005, domestic abuse cases had tended to be routinely discontinued absent victim support (see also Cretney and Davies, 1996). They also recalled how revised policy and guidelines in 2005 accompanied by mandatory training between 2005-8 endeavoured to address routine discontinuance. The new policy and guidelines encouraged pursuance of prosecutions, safety considerations permitting, but emphasised that a nuanced balancing of evidential and public interest factors was still necessary.

In practice, however, the new policy, guidelines and training appeared implemented as a tenacious pursuit and translated into,

'Just push it and push it as far as it will go' (Prosecutor 1).

Meaning that after 2008 the perception was that unsupportive victims were invariably being required by prosecutors to come to court to testify, despite their stated wish to have the matter terminated. This insight accords with research conducted by Hall in 2009 in which a Chief Crown Prosecutor attested that summons would now be the 'proper' way to proceed absent victim support (Hall, 2009; 145).

Eleven years later in 2017, prosecutors I interviewed were not so clear about the advantages summons offered. Prosecutors were now, largely, aware of the complexity pertaining to the decision to prosecute absent a supportive complainant. Prosecutor 2 understood the matter to be finely balanced and the factors he cited as relevant in deciding how to proceed were typical of those expressed by most prosecutors interviewed. The factors he weighed up fell into two broad categories. The first had to do with the seriousness of the offence; whether children were present, the extent of the injury and whether the defendant had like previous convictions. These are features of the offence that traditionally aggravate the sentence and are therefore aspects that are more likely to justify and require punishment and condemnation through prosecution if present. The other factors had more to do with risk assessment; whether there was a history of violence and whether parties were likely to reconcile. The implication was that if there was a history of violence and if parties were more likely to continue a relationship the more likely it would be that the case merited prosecution due to increased risk to the victim. Prosecution was seen to carry advantages in these circumstances because bail conditions prohibiting the defendant from contacting the victim would likely continue and because ultimately sentence would serve to protect the victim from future harm. 
Prosecutor 2's weighing up of these factors was reflective of the approach most prosecutors said they adopted. They were all factors that treated the woman's retraction as a trigger for considering the merits of ongoing prosecution but retraction appeared, at least in the absence of stating it expressly, not to act as a factor to be weighed into the mix. It seems that women's voices were being heard only to the limited extent that it prompted review of the case, not to the extent that acceding to what she wanted might also have been considered to have empowering value or have been the right thing to do given her unique understanding of the power dynamic between her and her abuser.

Whilst most prosecutors professed to employing a more detailed analysis of the advantages and disadvantages of summonsing the reluctant witness, 6 out 9 prosecutors perceived that significant numbers of colleagues were still obtaining a summons as a matter of routine. Prosecutor 4 summed up the position;

'If she's unequivocally saying she doesn't want to attend, then I think the CPS do tend to summons'.

This suggests that even though prosecutors may be engaging with the possibility of not summonsing, they are reluctant to discontinue cases and frequently engage the practice in any event. Prosecutor 2 expressed concern that habitual use of summons, in essence a 'nodrop' approach, was being favoured by colleagues simply because it is

'the easy way to do it..."Let's issue a summons!" without maybe thinking about it as much as they should'.

Three prosecutors, all women, however articulated more awareness of the victim's voice or preference and how facilitating empowering outcomes might be dependent upon a respectful consideration of her preference. Victim retraction was considered

'the hardest thing for us. Because at what point do you intervene and potentially overrule someone's wishes? It's a difficult balance' (Prosecutor 7).

Showing awareness of the potential for secondary victimisation and the fallibility of the CJS more generally, another of the three prosecutors suggested that instead of forcing victims through the 'trauma' of the court process,

'if that can be avoided and a positive outcome achieved where the victim is safe and lead a... positive, healthy, happy life then surely that is the better thing to do? Decisions really have to be made on a case by case basis and these kind of blanket policies, I don't think are appropriate in domestic violence cases.' (Prosecutor 5).

This prosecutor considered whether a non-conviction restraining order in combination with a police referral to domestic abuse support agencies would be sufficient to protect the unsupportive victim, whilst affording the opportunity to adhere to her wishes.

However, despite themselves demonstrating awareness of occasions when prosecution may not be preferable, prosecutors 5 and 7 were more than aware that not all their colleagues 
approached DA in the same way. They expressed concern that other colleagues and managers (with whom they had to consult and ultimately defer-see below) regularly summonsed victims, treating them as hostile witnesses at trial if necessary.

Three of the nine prosecutors however indicated that the tendency to rely on summons is diminishing. This readjustment appears to have been prompted by recent ongoing elearning training in 2016- 17 which, according to prosecutors, highlighted the potential problems with the use of summonsing and promoted preference for evidence-led (or victimless prosecutions) where the victim is no longer supportive. This was delivered in four mandatory modules and required prosecutors to work through case studies (Prosecutor 2 ).

Prosecutor 1 outlined the shift that he perceived followed,

'I certainly think that 12 months ago, most prosecutors would have been, their first reaction to a withdrawal would have been to appoint a witness summons. It kind of takes the decision out of their hands. They don't need to worry. Just send the summons'.

But he went on to identify that since the recent training about victimless prosecutions,

'I do think there has been a change and it's not so trigger happy'.

Prosecutor 9, a domestic abuse 'champion'11 agreed that,

'at the moment, there is a tendency to not necessarily summons. To look at cases as individual cases. Decide whether or not there is any merit in summonsing'.

The third prosecutor who did not identify the 'working practice' was relatively new to the service having worked there for just over a year. She herself observed and practiced tenacious DA prosecutions but was the only prosecutor not to identify routine summonsing had been practiced previously or still did occur. She suggested that the practice is

'not encouraged. It's very much seen as the last resort' (Prosecutor 8).

The latest training, undertaken by recently recruited prosecutor 8 , might provide an explanation for why she was the only prosecutor not to identify there is or ever was a practice of routine summonsing and suggests that there is sensitive and positive change afoot in the service in terms of practising the 'victim-informed' approach.

Despite evidence that since training in 2016- 17 prosecutors may be beginning to draw back and not assume summonsing is always desirable, according to eight of the nine prosecutors in the sample, the practice appears to have been cultivated between 2008-2016-17. The approach is akin to 'no-drop' prosecution praxis, at least in its 'soft form' (Buzawa and Buzawa, 1996). The next section examines how managerial pressures may have contributed to the tendency despite guidance that clearly advocates the use of summons as a last resort.

\section{Reaching the decision to pursue or discontinue the case: Techniques or 'working rules' of} NPM 
a) Policy objectives: Taking domestic abuse seriously

A preferred technique of managerialism is the deployment of organisational objectives that establish preferred and consistent modes of working. In the area of intimate partner abuse, CPS guidelines immediately establish the climate; 'domestic abuse offences are regarded as particularly serious' (CPS, 2014). More precisely, as part of broader government Violence Against Women strategies, the CPS aims 'to bring more perpetrators to justice as well as further protect victims of [domestic] abuse' (CPS, 2017a).

There is no doubt that prosecutors in my sample considered domestic abuse distinct from other 'general crime' or assault and the majority of prosecutors recited that domestic abuse is considered a 'priority' for the service. When pressed about why domestic abuse holds this elevated status there was universal consensus about the 'seriousness' of this type of offence. Several prosecutors made a link to the seriousness of the offence and the part the CPS must play in ending DA.

'Well, I mean, obviously [laughs] dare I say, right, this is serious. It happens in private when people are vulnerable. It's not the sort of thing we can have in a civilised society, is it? It has to be stamped out and prevented' (Prosecutor 2).

Prosecutor 3 added that effective prosecution and conviction through criminal law can be a means of expressing actual and figurative condemnation of certain behaviour thereby having deterrent effect. Mirroring policy principles, prosecutor 3 considered the CPS role to

'put domestic violence in the public forum. It needs to try and stamp out domestic abuse. Basically, they have been identified as cases that we need to do everything we can to actually get justice and see that they are being looked at correctly and basically explore all sorts of avenues to try and stop it happening' (Prosecutor 3 ).

These claims are reminiscent of Packer's crime control paradigm (Packer, 1964) and of analysis by Michelle Madden-Dempsey (a former expert DA consultant to the CPS) concerning the role and value of criminal prosecutions. Specifically, they mirror MaddenDempsey's assessment of prosecutorial action having consequential value insofar as it results in actual consequences; for example, it might result in conviction and successive punishment of perpetrators, the reduction of crime itself or people's anxiety about crime (Madden-Dempsey, 2009: 60). Prosecutions also articulate expressive value which is not consequential but intrinsic. This is akin to the symbolic value of denouncing wrong-doing and exculpating the victim. Madden-Dempsey thinks of the criminal 'charge' as having preliminary expressive value through accusatorial denouncement whereas conviction offers more finality through concrete condemnation (Madden-Dempsey, 2009: 68).

Both the consequential and intrinsic value of prosecuting domestic violence was iterated by prosecutor 6 ,

'Instead of going, oh yeah, let's get rid of this one. It's about looking at the implications of the wider community and the kind of rippling effect of how it will impact society as a whole.' 
It is noteworthy that I identified prosecutor 6 as favouring tenacious prosecutions by regularly summonsing reluctant women to secure convictions. For this prosecutor, convictions were invariably considered the preferable outcome in domestic abuse cases. It is quite possible that her articulation of the role of criminal prosecutions as part of a greater pursuit to challenge the acceptability of intimate partner abuse in society generally has fuelled, or at least has supported her commitment to obtain convictions, through the use of summons whenever necessary. Madden-Dempsey's understanding of the role of the prosecutor is directly referenced in the United Nations special rapporteur on violence against women report (United Nations 2009; 27). The CPS affirms and cites the report (CPS, 2017a) which details that '[f]or a State action to realize... intrinsic value [of prosecutions], it must not be a one-off instance of condemnation, but in fact it must systematically engage with domestic violence and condemn it' (United Nations 2009; 27). Discontinuing cases on request, it follows, is not a strategy readily advocated by the CPS.

\section{b) Deferring to management}

Managerialism encourages 'effectiveness' by developing consistent working approaches to meet organisational goals. Consistency is typically achieved through the expansion of management personnel who are tasked with overseeing operations. If expectations about decision-making are clearly defined, and discretion is set within restrictive parameters, decision-making can become routinised and can effectively result in a de-skilling or downgrading of the skilled worker's role (here the Crown Prosecutor) (Kilkauer, 2015). Flynn describes this in terms of a shrinkage of 'work autonomy' or a 'de-professionalisation of expert labour' (Flynn, 1999; 30). Where managers are ensuring reliable deployment of discretion in line with organisational objectives, their presence is likely to contribute to fewer decisions being made against the cultural grain and might be said to have a constraining effect on the professional workforce.

The other way that decision-making powers of professionals might be curbed as a result of NPM is if managers themselves make the decision. Due to the seriousness with which domestic abuse is viewed within the service, most of the prosecutors interviewed were required to consult with their line manager (the 'Level $D$ ') before taking any decision to discontinue or terminate domestic abuse proceedings. Some more senior and experienced prosecutors informed me that they had previously been obliged to consult with their manager but recently were told they were no longer required to do so. Whilst this may appear to afford individual prosecutors discretion, the change appears to have taken place because these prosecutors were trusted to exercise their discretion in accordance with now familiar CPS policies, targets and management expectations. Confirming this, prosecutor 3 , (who now had permission to take the decision herself) commented that one's line manager still set the tone for the decision you were likely to take. For her team,

'It tends to be, well, to be encouraged to apply for witness summonses, quite often. I think it depends who is, basically, the 'Level D' at the time as towards the sort of approach you take.' 
Here in evidence, managerialism's ability to 'think on its feet'; initially insisting managers take the decision and then reducing 'hierarchical decision-making' (Jones, 1993; 188) to free-up valuable managerial time once the 'working practice' was established.

c) Streamlining processes: Digitalisation

The recent digitalisation of CPS case files and the consequent elimination of the 'paper file' was intended to streamline and modernise processes in line with the tenets of managerialism; cost and time efficiency being paramount and maximising worker productivity. Digitalisation now sees prosecutors assigned a digital case load (Prosecutor 3 indicated hers included 145 files) and each prosecutor is presented with a digital task list every day (Prosecutor 3 indicated that her task list that day was 7 pages long). With prosecutors aware that the volume of work being undertaken by them is now being monitored by managers, prosecutors described feeling under further pressure to complete daily task lists quickly. The time pressures imposed on prosecutors through digital working doubtless impact on the thoroughness with which information or evidence can be considered;

'There's never enough time to do anything... it sort of feels like you're working against [it] to get it all done quickly' (Prosecutor 2). ${ }^{12}$

I have already suggested that demands for efficiency evolve routinised decision-making as Packer and Garland's cautionary analysis of managerialism predicts (Packer, 1964; Garland, $2001 ; 18)$. In domestic abuse cases, the use of summons represents an efficient solution to the obstacle of victim retraction because of the time saved avoiding a thorough consideration of victim risk assessment from a variety of sources (victim retraction statements, police risk assessments, Independent Domestic Violence Advocates representations or information known to police 'witness care' officers). Summons therefore achieves two NPM demands; it is time efficient and it simultaneously espouses the organisational objective to actively condemn domestic abuse.

\section{d) Austerity}

Since 2010, the coalition and Conservative governments have governed through a political logic of austerity, a priority which, just as NPM, makes demands for 'economy'. Austerity, a political rather than an economic concept (Bramall et al, 2016), aims to return economic stability through the seemingly common sense but arguably 'economically illiterate' (Bramall et al, 2016; 121), notion of spending within one's means. The government itself rarely prefers the term, rather it is a label that is ascribed by others to describe the 'dramatic and severe spending cuts' (Bramall et al, 2016; 119) designed to significantly reduce budgetary deficits in preference to raising funds through taxation. As managerialism is specifically designed to facilitate cost-efficiency, NPM's methods gain particular credence in times of austerity. Budgetary cuts are presented in terms of efficiency savings.

The CPS experienced a $£ 185$ million cut to their budget between 2009 and 2015 (Hansard, 2017). Such cuts play into the hands of managerial techniques that already prioritise efficient returns from limited means. Prosecutors I interviewed were under no doubt that 
budgetary cuts, attributed to austerity measures, contributed to the pressure they felt to undertake work expeditiously. Prosecutor 2 noted that,

'Lots of people have gone. It just seems to me that there is a smidgen of what was left. I mean, I know that you are told that there is less magistrate's work now, but it doesn't feel like it. It sort of still feels like you are working against the line to get it all done quickly'.

Prosecutor 2 was correct that the numbers of cases brought to magistrates' courts nationwide declined by just over 100000 in the period 2010- 2015, falling from 641000 cases to 539000 (Hansard, 2017)..$^{13}$ Prosecutors are also likely to be accurate, however, when they identify that they have no sense that the number of cases that must be prepared by each individual prosecutor has reduced. This is because between 2010 and 2015, 2400 members of staff left the service, largely through voluntary redundancies, in order to meet the $40 \%$ reduction in the staffing budget in the same period (Hansard, 2017).

In the context of the 'whopping' ${ }^{14}$ reduction in staff numbers, it is clear how the need to make efficient and expeditious decisions, with almost factory like predictability, becomes acute. Operating with a working presumption that reluctant victims will be summonsed, short-circuits the need to engage in the time intense detailed analysis of the possible merits of doing so, whilst simultaneously expressing condemnation as required by policy objectives.

\section{e) Statistical analysis}

Monitoring and surveying performance and target attainment through means of computerised bureaucracy is characteristic of NPM. To facilitate appraisal of domestic abuse cases (notably the conviction rate), domestic abuse must be 'flagged' on the CPS computer system. 'Flagging' a case means that a coloured marker appears on the digital case file so that it is readily identifiable as domestic abuse (as defined by the Home Office) and outcomes can be collated. All prosecutors in the sample were aware that 'flagging' enabled the CPS to compile statistics which were monitored 'as a measure of success' (Prosecutor 2). Statistics were largely considered a concern for managers but nonetheless prosecutors described how statistics 'filter through' (Prosecutor 2) to them. Some prosecutors reported that statistics were emailed for information purposes only. Others received an explanation of how 'well' the team were doing in prosecuting domestic abuse and what they needed to be aware of 'moving forward' bearing in mind, recognised prosecutor 7, that each of the 13 CPS areas are ranked. Tables are compiled comparing the 13 CPS area conviction rates and are readily circulated and available. Here, clearly visible, is evidence of how the CPS, in the absence of external competitors, is encouraged to compete with itself for best 'output' in line with the tenets of New Public Managerialism.

For one prosecutor the culture that statistical analysis of cases imbued was not one that sat comfortably with her,

'I've never been a manager, so I don't- it's one of the reasons I get so frustrated with working for the CPS, I have to say. It's all about, to me it just seems like it is all 
becoming about targets and statistics and not about the individuals. There's not so much focus on victims. I've never been a manager, so I don't know what goes on in these management meetings and how much it is drummed into you but I always get the impression that it is very very important that targets are met and numbers of successful prosecutions are such and such.' (Prosecutor 5)

This seems to mirror the notion that New Public Managerialism constructs the public as consumer in the sense that what becomes prioritised is not so much meeting individual needs in an ideological or principled way so much as meeting market demands for efficient 'output' (Jones, 1993) and performativity. In the case of the CPS this is measurable through, inter alia, the conviction rate. There was a sense amongst prosecutors that the CPS are always monitoring area performance, particularly as compared to other CPS areas. Prosecutor 8 explained,

'My experience is that the conviction rate is... there is a very close eye kept on that for obvious reasons... and obviously because you are flagging DV, if there is a conviction rate falling or dropping or whatever they are able to monitor it.'

These auditing processes are also the means by which parliament can hold the Crown Prosecution Service to account. The government's Chief Legal Advisor, the Attorney General, oversees the work of the Director of Public Prosecutions and her organisation and is answerable to parliament for CPS performance. Rates of CPS convictions or discontinuances are also used by the Justice Select Committee that examines CPS expenditure, administration and policy. The Committee is tasked with publishing reports that government must respond to, to explain or justify how it is spending taxpayers' money. However, if it is the CPS as an institution that is being held accountable to parliament for conviction rates by virtue of such statistical tracking, how are decisions of individual prosecutors affected? I identified two ways individual prosecutorial decision-making is impacted by the monitoring of area or nationwide statistics.

The first way is through an institutional-wide response which might be triggered if a set of statistics indicated, for instance, a slump in conviction rates. In such circumstances prosecutor 2 suggested that the CPS might react by rolling out compulsory training amongst prosecutors to address the issue. Such training has the potential to instil a wider cultural shift in the service, as evidenced in 2005- 2008. This chimes with NPM's ability to set and implement organisational strategies which have the effect of controlling public servants (prosecutors) and regulating professional independence (Exworthy and Halford, 1999).

\section{f) Risk and responsibility}

In addition to prompting changes to institutional wide practice and culture, the second way poor performance figures might affect prosecutorial decision-making is through management scrutiny of individual decisions. Prosecutor 7 understood that a poor monthly performance might probe further investigation by managers into particular files. Individual cases might be analysed and questions asked about why the case was dropped. In any event, a more thorough examination of prosecutorial decision making takes place in all cases that are recorded as an 'adverse outcome'. An adverse outcome, explained 
prosecutor 1 , is anything that does not result in the defendant being convicted of at least one offence and is an 'unsuccessful' outcome; whether discontinued, withdrawn, offered no evidence, dismissed at half time or after full trial. All 'adverse outcomes' are studied by managers to establish the reasons for not obtaining a conviction and to see if 'improvements' could have been made (Prosecutor 6). Prosecutor 9 confirmed that,

'Adverse outcomes are particularly looked at to see why. Was it a case of a victim not coming to court and therefore we didn't have the evidence? Is it a case the victim came to court but didn't come up to proof [or] didn't give evidence very well? ... It's that aspect of things that they look at as to why cases, for want of a better word, failed. Why didn't we secure that conviction? They look to see whether we can learn any lessons from it.' (Prosecutor 9)

That being so, prosecutors in the sample were mindful that any decision they took that might contribute to a reduction in the conviction rate, might be open to inquiry. If a case fails on the day of trial because a summons was not secured then this may be interpreted as inaction on the part of the prosecutor. Conversely, if a woman has been summonsed and fails to answer the summons then the prosecutor has done everything within their power (short of issuing a warrant for her arrest) and cannot be criticised.

One area domestic abuse 'champion' suggested that if a prosecutor did not summons it would not lead to automatic criticism because of growing awareness that summonsing may not necessarily be preferable, particularly if it discourages women to seek help from criminal justice agencies in the future. Nonetheless even she accepted that prosecutors realised that adverse outcome cases would be examined more rigorously than cases that resulted in conviction and that prosecutors would feel or could be held accountable for decisions leading to acquittals. In short, if a prosecutor fails to push for a domestic abuse conviction, the decision will be one that is scrutinised and the prosecutor will need to have justified the decision in their written review of the case. Managerial appraisal of files therefore contributed to a sense of professional and personal responsibility to meet organisational objectives. Here, again, evidence of the effect of NPM, which demands compliance with policy objectives (to 'take domestic abuse seriously') and holds those tasked with delivering standards and guidelines to account through regular monitoring and inspections (Garland, 2001: 120).

As a result, what seems to be implied here is how NPM can create a culture of fear and insecurity. Prosecutor 4 confirmed that when making the decision to summons,

'[Prosecutors] will think of themselves, individually, first of all. They are all civil servants and they want to cover their backs. First rule.'

Prosecutor 1 agreed that relying automatically on summons is the least 'dangerous' option for prosecutors because they have demonstrated understanding that every option must be explored to obtain 'justice' for the domestic abuse victim and criminal sanctions for the defendant. Summons, he surmised,

'absolves their responsibility for making decisions [not to prosecute]' (prosecutor 1). 
Manager repercussions were feared not only in relation to professional criticism for inadequate decision making. The fear also included how management would criticise them should something happen to the victim in the future where a case had been terminated 'prematurely':

'What always used to worry me was, you know, am I going to get one of these cases where it doesn't go ahead or we can't prosecute it properly... and then she's going to be murdered. People are going to say, sorry you were the SCP. ${ }^{15}$ Horrendous...' (prosecutor 8).

When asked if that meant that blame might be apportioned to the individual prosecutor if a pre-ceding case had been dropped, she replied,

'Isn't that the CPS to a fault though? They would just hang you out to dry, wouldn't they, I think'.

Indicating that he did not prefer the practice of routine summonsing, prosecutor 1 suggested that this was because he had had some management experience and concluded that he was probably more self-assured in his decision making than other people might be. However, even he recognised the potential for repercussions,

'Touch wood I haven't had one that's come back to bite me yet'.

When prompted to expand he answered,

'I suppose if you really sat and thought about every case, you would have this slight concern that, you know, the victim could be, I don't know, subject to a further serious or even fatal assault. But, we are dealing with so many of these cases, you know, on a daily basis that you have to kind of just get on with it.'

For this experienced and senior prosecutor, whilst being aware of the gravity of the decision he was taking, distancing himself from responsibility for any future harm that may come to the victim was the sensible and pragmatic approach to take.

As NPM demands efficiency and speed to achieve cost effectiveness, prosecutors develop strategies of coping with demands of heavy workloads. As domestic abuse caseloads require engagement with the cruelty and barbarity of others, one way productivity might be maintained is by resisting full engagement with the suffering contained in the victim's account. Prosecutors do not receive training to cope with emotional 'contagion' and must informally manage its impact (Ellison and Munro, 2017; 198). By practising emotional detachment, prosecutors are able to minimise 'vicarious trauma' which allows prosecutors to step aside from feelings of guilt and responsibility (Ellison and Munro, 2017), perhaps evident with Prosecutor 1 cited above. Decision-makers can practice 'detachment, disbelief and denial of responsibility in order to avoid ... becoming emotionally overwhelmed by the accounts of persecution and violence routinely encountered' (Ellison and Munro, 2017; 198). This emotional detachment or disengagement with shocking occurrences is a habit 
that understandably evolves for the purposes of self-protection but it inevitably means that victim accounts feel unreal and the severity or even veracity of what has been experienced by the victim is diluted.

In the context of prosecuting domestic abuse within NPM constraints, crucial coping strategies avert the need to re-live or imagine the details of a crime but this can result in a withdrawal from engaging with the needs of the victim or from a detailed assessment of what might facilitate her 'capability set' (Nussbaum, 2011). In line with Ellison and Munro's 'trauma-informed lens', routinely summonsing allows prosecutors to demonstrate a commitment to 'taking domestic abuse seriously' whilst ensuring a measure of emotional self-preservation. Detachment also preserves and permits clarity of thought which facilitates efficient professional decision making and task completion. Withdrawing emotionally from the details of the abuse therefore serves the prosecutor in effecting expeditious decisions and assists in managing the pressures of managerial targets, high workloads and the impacts of austerity.

\section{Conclusion}

The principles and practices of New Public Managerialism have been evident in the English and Welsh criminal justice system since at least the mid-1990s (McGlaughlin et al, 2001). Three key strategies have been deployed since then; modernisation, efficiency and financial prudence; target setting, performance monitoring and managerial accountability and lastly increased standardisation in policies and practices which has the effect of curbing the decision-making autonomy of its professionals (Raine and Willson, 1997: 82). This article has drawn out the ways in which NPM's strategies currently operate, often in unacknowledged ways, to influence how 9 prosecutors in the South of England make decisions in cases of intimate partner abuse where the victim no longer supports criminal prosecution.

The data uncovers a 'working practice', present in 2017 amongst the sample, that can be summarised as a tendency for Crown Prosecutors to routinely rely on summonsing reluctant victims of intimate partner abuse to give evidence at trial. This approach appears to have emerged since 2008. According to the majority of prosecutors interviewed the 'working practice' appears closer to soft 'no-drop' (Buzawa, 2003) or 'social change' (Nichols, 2014) strategies of prosecuting domestic abuse rather than the 'victim-informed' approach advocated in CPS policy and guidelines. The potential consequences for victims of routinely relying on summons include overlooking risks to her safety during the course of proceedings or immediately afterwards (Catteneo et al, 2009), the risk that she no longer trusts the criminal justice system to act in her best interests in the future (Buzawa, 2000) or the risk that the coercive behaviour of her abuser is simply replaced with coercive practices of the state (Mills, 1999) thereby undermining her own emotional well-being and belief in her ability to be autonomous (Winick, 2000).

The article proposes some of the possible reasons for the emergence of the 'working practice' to the extent that it is identified amongst the sample. It uncovers how concealed, tacit and hitherto unacknowledged strategies of New Public Managerialism contribute to a prosecutorial reliance on summons. At its core NPM seeks efficiency and service delivery in 
line with organisational objectives and targets. As achieving high rates of convictions in domestic abuse cases is celebrated (CPS, 2017a) the article explains that the routine use of summons serves as an expeditious yet effective way of meeting managerial demands for efficiency whilst effecting CPS policy objectives.

If the primary research reveals a prosecutorial practice habitually disinclined to adhere to a victim's request to terminate proceedings, the sample also reveals preliminary indications that the 'working practice' may not enjoy wholehearted support from many prosecutors. Moreover, following recent training in 2016-17, three out of nine prosecutors were reluctant to accept that routine summons persisted in the service. Instead, they suggested that 'victimless prosecutions' were being encouraged and each case was being reviewed on its own terms. Whilst there remained a presumption in favour of prosecuting domestic abuse cases, they indicated a nuanced balancing exercise based on information provided from victims, police and third parties was taking place where complainants were unsupportive. Thus, there is some evidence from the research that positive and sensitive change- towards a more nuanced or 'survivor-defined' approach to prosecuting domestic abuse- is afoot. This marks a move towards the stated CPS approach to prosecuting domestic abuse (CPS, 2014) and appears to be taking place, albeit at a preliminary stage, despite the pressures and demands of NPM.

\section{Acknowledgements}

See title page

\section{Declaration of Conflicting Interests}

The author declares her previous employment at the Crown Prosecution Service between 2007 and 2014 and her continued employment as a freelance advocate appearing in court on behalf of the Crown Prosecution Service since 2014.

\section{Funding}

The author disclosed receipt of the following financial support for the research, authorship, and/or publication of this article: This research was supported by the Kent Law School $50^{\text {th }}$ Anniversary Research Scholarship.

\footnotetext{
Notes

${ }^{1} 1$ in 3 cases that do not result in conviction come as a result of victim retraction, non-attendance at trial or turning hostile as compared to 1 in 10 for other crimes (CPS, 2016).

${ }^{2}$ A Crown Prosecutor has discretion to discontinue a case under s23 Prosecution of Offences Act 1985.

${ }^{3}$ I use the pronoun 'her' as according to CPS statistics from $2015-16,83.3 \%(71,706)$ of domestic abuse victims were women, as compared to $16.7 \%(14,406)$ men (CPS, 2016).

${ }^{4}$ As per The Prosecutor's Code this 'evidential test' is the first test that must be passed before prosecution. The second test is whether it is in 'public interest' to prosecute (CPS, 2013).

${ }^{5}$ Hearsay evidence may be admissible by virtue of s116(2)e Criminal Justice Act 2003 if the victim is in fear or s114(1)d if it is considered in the 'interests of justice' to do so.

${ }^{6}$ The court has power to issue a summons under s169 Serious Organised Crime and Police Act 2005.

${ }^{7}$ For a comprehensive account of NPM as it affects social work, health services and education see Exworthy M and Halford S (1999) Professionals and the New Managerialism in the Public Sector. Open
} 
University Press. For an account of NPM in British local government see for example, Gerry Stoker (1999) The New Management of British Local Governance. Macmillan.

${ }^{8}$ The CPS implemented 'Core Quality Standards' in December 2009 (renamed 'Casework Quality Standards in 2014) CPS, Casework Quality Standards available at https://www.cps.gov.uk/publications/casework quality standards/index.html (accessed 31 October 2017).

${ }^{9}$ In the CPS, Crown Prosecutors and Senior Crown Prosecutors fall into teams managed by District Crown Prosecutors overseen by Assistant Chief Crown Prosecutors managed by Chief Crown Prosecutors who are accountable to the Director of Public Prosecutions. Area Business Managers also assist the Chief Crown Prosecutors. It is notable that managerialism is characterised by unrelenting organisational restructuring in its quest for streamlined working; the CPS has seen countless reconfigurations of its management structures and organisation.

${ }^{10}$ Buzawa et al's 2000 report outlined findings from the Quincey District Court project which observed 353 abused women over a period of 7 months. The report notes that women who experienced no-drop prosecution policies were 2.5 times less likely to report recidivist abuse in the proceeding 6 months.

${ }^{11}$ The sample comprised 6 women and 3 men ( 6 Senior Crown Prosecutors, 1 Crown Prosecutor and 1 Associate Prosecutor).

${ }^{12}$ As a domestic abuse champion, this prosecutor had enjoyed attending joint meetings with police, courts and IDVAs. These meetings were forums where best practice was disseminated and poor practice considered. They no longer take place according to Prosecutor 9.

${ }^{13}$ Prosecutor 3 used the same words, 'I don't have enough time to do anything'. Prosecutor 4 said, 'There is never enough time'. Prosecutor 5, 'There just aren't enough hours in the day or enough prosecutors in the office to be doing the job that needs to be done'. Prosecutor 7, 'I don't feel I have enough time to prepare'. Prosecutor 8 stated that she did not have enough time to deal with DA. Prosecutor 9 stated that she did not always feel she had enough time to prepare for court.

${ }^{14}$ The reduction in cases being brought to court is arguably a result of spending cuts, in times of austerity, experienced by the police.

${ }^{15}$ Karl Turner MP speaking in parliament in January 2017 (Hansard, 2017).

16 'Any incident or pattern of incidents of controlling coercive or threatening behaviour, violence or abuse between those aged 16 or over who are or have been intimate partners or family members, regardless of gender or sexuality' (cited in CPS, 2014).

${ }^{17}$ Senior Crown Prosecutor.

\section{References}

Bell E (2011) Criminal Justice and Neoliberalism. Springer.

Bell J (2006) Doing Your Research Project: A guide for first time researchers in education, health and social science. Open University Press.

Bennion F (1986) The New Prosecution Arrangements. CLR 3.

Bettinson V and Bishop C (2017) Evidencing domestic violence, including behaviour that falls under the new offence of "controlling or coercive behaviour". International Journal of Evidence \& Proof 22(1) 3.

Bramall R, Gilbert J and Meadway J (2016) What is austerity? New Formations 87(87) 119. 
Braun V and Clarke V (2006) Using thematic analysis in psychology. Qualitative research in psychology 3(2) 77.

Brown W (2015) Undoing the Demos. MIT Press.

Bryman A (2012) Social Research Methods. Oxford University Press.

Burton M (2008) Legal Responses to Domestic Violence. Cavendish 2008.

Buzawa E and Buzawa C (1996) Do Arrests and Restraining Orders Work? Sage Publications.

Buzawa E and Buzawa C (2003) Domestic Violence: The Criminal Justice Response. Sage Publications.

Buzawa E et al (2000) Response to Domestic Violence in a Pro-Active Court Setting: Final Report. NCJ 17

Catteneo L, Goodman L and Epstein D (2009) The Victim-Informed Prosecution Project: A QuasiExperimental Test of a Collaborative Model for Cases of Intimate Partner Violence. Violence Against Women 15(10): 1227.

Cretney A and Davis G (1996) Prosecuting 'domestic' assault. Criminal Law Review 162.

Cretney A and Davis G (1997) Prosecuting domestic assault: Victims failing courts or courts failing victims? The Howard Journal of Crime and Justice 36(2) 146.

Crown Prosecution Service (2008) 'Evaluation of the national domestic violence training programme 2005-2008' Available at

https://www.cps.gov.uk/publications/equality/evaluation of national domestic violence training programme.html (accessed 29 June 2017).

Crown Prosecution Service (2013) The CPS: Code for Crown Prosecutors. Available at https://www.cps.gov.uk/publications/docs/code_2013_accessible_english.pdf (accessed 16 October 2017).

Crown Prosecution Service (2014) Domestic Abuse Guidelines for Prosecutors.

Available at http://www.cps.gov.uk/legal/d_to_g/domestic_abuse_guidelines_for_prosecutors/ (accessed 30 October 2017).

Crown Prosecution Service (2016) Violence Against Women and Girls Crime Report 2015-16.

Available at

https://www.cps.gov.uk/sites/default/files/documents/publications/cps_vawg_report_2016.pdf (accessed 17 October 2017).

Crown Prosecution Service (2017a) Violence Against Women and Girls' Report.

Available at http://www.cps.gov.uk/publications/docs/cps-vawg-report-2017.pdf (accessed 16

October 2017).

Crown Prosecution Service (2017b) Victims and Witnesses, Available at www.cps.gov.uk/victims_witnesses/reporting_a_crime/decision_to_charge.html (accessed 30 October 2017).

Ellison L (2002) Prosecuting domestic violence without victim participation. The Modern Law Review 65(6): 834. 
Ellison L and Munro V (2017) Taking trauma seriously: Critical reflections on the criminal justice process. International Journal of Evidence and Proof 21(3): 183.

Exworthy M and Halford S (1999) Professionals and the New Managerialism in the Public Sector. Open University Press.

Flynn R (1999) Managerialism, Professionalism and Quasi-Markets in Exworthy M and Halford S (1999) Professionals and the New Managerialism in the Public Sector. Open University Press.

Foucault M (2004) in Senellart M (ed) The Birth of Biopolitics: Lectures at the College de France, 1978-79. Picador.

Garland D (2001) The Culture of Control: Crime and Social Order in Contemporary Society. Oxford University Press.

Goodman L et al (2016) Survivor-Defined Practice in Domestic Violence Work: Measure Development and Preliminary Evidence Link to Empowerment. Journal of Interpersonal Violence 163- 185.

Gottschalk M (2012) The prison and the gallows: The politics of mass incarceration in America. Cambridge University Press.

Hall M (2012) Victims of crime: Policy and practice in criminal justice. Routledge.

Harvey D (2005) A Brief History of Neoliberalism. Oxford University Press.

Hansard online (2017) Crown Prosecution Service: Funding. Vol 619. Available at https://hansard.parliament.uk/Commons/2017-01-11/debates/3CCEE460-C6B8-44B5-A7C3677947ECEA19/CrownProsecutionServiceFunding (accessed 16 October 2017).

HM Government (2016) Strategy to end violence against women and girls: 2016 to 2020 available at https://www.gov.uk/government/publications/strategy-to-end-violence-against-women-and-girls2016-to-2020 (accessed 30 October 2017).

House of Commons (1975) Report from the Select Committee on Violence in Marriage Together with the Proceedings of the Committee. Her Majesty's Stationery Office.

Hoyle C and Sanders A (2000) Police response to domestic violence: From victim choice to victim empowerment. British Journal of Criminology 40(1): 14.

Jones C (1993) Auditing Criminal Justice. British Journal of Criminology 33(2): 187.

Jones R (1999) Guardianship for coercively controlled battered women: Breaking the control of the abuser. Geo IJ 88: 605.

Kilkauer T (2015) What is Managerialism? Critical Sociology 41(7-8): 1103.

Lacey N (1991) Government as manager, citizen as consumer: The case of the Criminal Justice Act 1991. The Modern Law Review 57(4): 534.

Larner W (2000) Neo-liberalism: Policy, Ideology and Governmentality. Studies in Political Economy 5: 13. 
Leveson B (2015) Review of Efficiency in Criminal Proceedings. Judiciary of England and Wales.

Madden-Dempsey M (2009) Prosecuting Domestic Violence: A Philosophical Analysis. Oxford University Press.

Maguigan H (2003) Wading into professor Schneider's 'Murky Middle Ground' between acceptance and rejection of criminal justice responses to domestic violence. Journal of Gender, Social Policy \& the Law 11: 427.

Mauthner N and Doucet A (1998) Reflections on a Voice-centred Relational Method in Ribbens J and Edwards R (eds) Feminist Dilemmas in Qualitative Research: Public Knowledge and Private Lives.

Sage.

McGlaughlin E, Muncie J and Hughes G (2001) The permanent revolution: New Labour, new public management and the modernization of criminal justice. Criminal Justice 1(3): 301.

Mattravers M (2010) The victim, the State and civil society in Bottoms A and Roberts J (eds) Hearing the Victim: Adversarial justice, crime victims and the State. Routledge.

Mills L (1999) Killing her softly: Intimate abuse and the violence of state intervention. Harvard Law Review 550.

Nichols A (2014) No-Drop Prosecution in Domestic Violence Cases: Survivor-Defined and Social Change Approaches to Victim Advocacy. Journal of interpersonal violence 29(11): 2114.

Nussbaum M (2011) Creating Capabilities: The Human Development Approach. Harvard University Press.

Office for National Statistics (2016) Domestic abuse in England and Wales: Year ending March 2016. Available at

file://C:/Users/adp28/Downloads/Domestic\%20abuse\%20in\%20England\%20and\%20Wales\%20year \%20ending\%20March\%202016.pdf (accessed 10 November 2017).

Packer H (1964) Two Models of Criminal Process. University of Pennsylvania Law Review 1.

Peck J (2010) Zombie neoliberalism and the ambidextrous state. Theoretical Criminology 14(1): 104.

Phillips C (1981) Report of the Royal Commission on Criminal Procedure. Her Majesty's Stationery Office.

Queen's Speech (2006) Full text of the Queen's speech. Available at http://news.bbc.co.uk/1/hi/uk_politics/6150274.stm (accessed 30 October 2017).

Raine J and Willson M (1997) Beyond managerialism in criminal justice. The Howard Journal of Crime and Justice 36(1): 80.

Saccuzzo D (1998) How should police respond to domestic violence: A therapeutic jurisprudence analysis of mandatory arrest. Santa Clara Law Review 39: 765.

Stark E (1993) Mandatory arrest of batterers: A reply to its critics. American Behavioral Scientist 36(5): 651. 
United Nations (2009) 15 years of the United Nations special rapporteur on violence against women (1994-2009) A critical review. Available at

http://www.ohchr.org/Documents/Issues/Women/15YearReviewofVAWMandate.pdf (accessed 30 October 2017).

Walker L (2016) The Battered Woman Syndrome. Springer.

Watts S (2014) User skills for qualitative analysis: Perspective, interpretation and the delivery of impact. Qualitative Research in Psychology 11(1): 1.

Weick K (2007) The Generative Properties of Richness. Academy of Management Journal 50: 14- 19.

Winick B (2000) Applying the law therapeutically in domestic violence cases. UMKC Law Review 69: 33.

Wills D (1997) Domestic Violence: The Case for Aggressive Prosecution. UCLA Women's Law Journal 173.

Yin R (2003) Case Study Research: Design and Methods. Sage. 